\title{
高速引張におけるポリエステルフィラメント糸の 応力ーひずみ曲線
}

\author{
金沢大学工学部 喜成 年泰・放生 明廣・新宅 救徳・岩木 信男

\section{STRESS-STRAIN CURVE IN POLYESTER FILAMENT YARN FOR TENSILE DEFORMATION AT HIGH RATES}

\author{
By Toshiyasu Kinari, Akihiro Hojo, Sukenori Shintaku, and Nobuo Iwaki
}

(Faculty of Technology Kanazawa University 2-40-20 Kodatsuno, Kanazawa, 920 Japan)

\begin{abstract}
An impact tensile testing apparatus with cantilever type load cell was developed for obtaining stress-strain curves of polyester multi-filament yarn at various strain rates. The experimental results were compared with the numerical results derived from an over-stress theory. By using this apparatus, tensile tests of yarn at wide range of strain rate from $10^{-3}$ to $10^{2} \mathrm{~s}^{-1}$ could be performed in the same measuring system. The over-stress theory gave satisfactory interpretation of the stress-strain curves of polyester multi-filament yarn up to breaking point at low strain rate, and up to yielding point at high strain rate. The difference between the calcurated curve and experimental results at high strain rate seemed due to the temperature rise of yarn during extension.
\end{abstract}

(Received November 20, 1989)

\section{1. 緒言}

近年，轹維機械の高速化にともなって繊維の製造や加 工工程中に㧍ける系の運動速度が大きくなり，系が衝擊 的な張力を受ける機会が増してきたここのため蟣維材料 や製品の動的挙動を明らかにすることが重要であり，䋊 维の衝撃試験を行い，応力ーひずみ関係におよばすひず

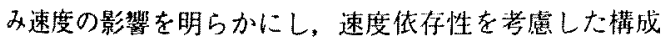
方程式を導く必要がある。

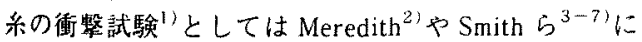
よる一連の研究などがあり，その他応力ーひずみ海線に およはす温度とひずみ速度の影桓なども测定されてい る8が、その庍力ーひずみ挙動を数式化する試みはなさ れていない。これらの实験には回転船あるいはレバー などにより糸を直接高速で引っ張るもの总や系の横衝 整実験から引張応力を推䇥するもの委などがある。これ らでは离速度写真存用いて測定された变位一時间曲線の 微分から閐接的に系の荷重を求める場合が多い。直接荷 重を測定するものとしては，圧電素子を利用した荷重㖕 を用いるものもあるが，引張り速度が大きくなると街重 計と試料の取り付け方法などが問題となってくる。
そこで本研究では，試料の取り付けを容易にし，かつ 検出感度を高めるために，小さな片持ちはりを利用した ロードセルを用いて糸にかかる荷重を測定する衝紧試駰 装置を試作し，ポリエステルマルチフィラメント系につ いて種々の引張速度における荷重一伸び曲線を求めた。 そして得られた枕力ーひずみ関係に拈よばすひずみ速惯 の影晦について，過应力模刑に基つく構成方程式により 検討した。

\section{2. 実験装置および実験方法}

\section{1 实験装置}

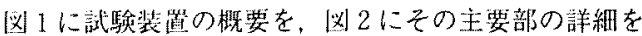

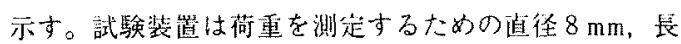
さ20 $\mathrm{mm}$ の片持ちはり(汹 $2(\mathrm{a}))$, 系に引張り速度を与 えるための外径 $18 \mathrm{~mm}$ ，言さ $145 \mathrm{~mm}$ の中をくり报いたア ルミ製入力棒(汹 $2(\mathrm{~b})$ ：重量48gf) 扰よびこれらを保持 するためのベースから成っている。网 2 (d)に示すよう に糸試料の上下端にアルミ小片(似 $2(\mathrm{c})$ ：画量0.35gf)

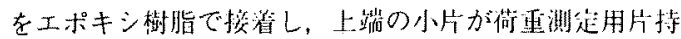
ちはりの上面に，下端の小片が入力棒の下䧋に接するよ うにそれぞれのスリット妾利用して取付ける。片持ち 


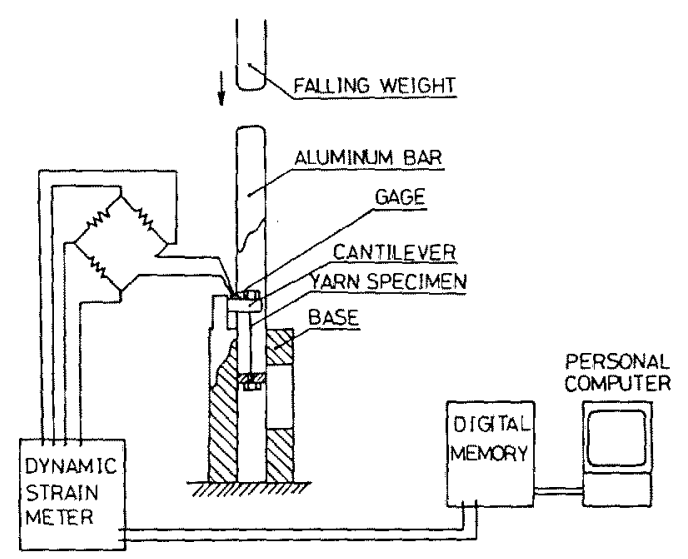

Fig. 1. Schematic diagram of tension measurement system.

はり上面はアルミ小片との接触を良くするために平らに してあり，人力棒を下方入押し下げることによって糸を 引張する。荷重を検出するためのひずみゲージ(共和電 業製 KSP-1-350)は先端か $515 \mathrm{~mm}$ の位置に貼り付け to

このひずみゲージを四 1 に示すように動ひずみ計(共 和電業製 CDV $-230 \mathrm{C}$ : 芯答周波数 $200 \mathrm{KHz})$ に接続 L，そ の出力をデジタルメモリ(岩崎通信機製 DM-7100)で測 定する。動ひずみ計の出うと倚重の関係は静何重によっ

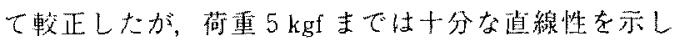

tio

また，乐試料の伸びを知るために図3のように、アル ミ棒下端の変位を光電式近接センサ(立石電気製 $\mathrm{EE}-\mathrm{SPZ}$ 形ファイバ付変謂光フォトマイクロセンサ)を 用いて以下の上うに測定した。同图に示されるように一 列に並べられたセンサ $\mathrm{s}_{1} \sim \mathrm{s}_{6}$ の出力を各々ラッチ回路を 経て抵抗 $r_{1} \sim r_{6} に$ 接続した。アルミ棒下端がセン井を横 切るにつれて抵抗 $r_{t}$ の出力電压 $E_{0}$ が, 四 $7(a) に$ 示すよ うに階段状に変化するのでこれを荷重と同時にデジタル メモリで記録し，アルミ棒下端が各センサを横切った時 間 $\mathrm{t}_{1} \sim \mathrm{t}_{6}$ 測定する。センサ $\mathrm{s}_{1} \sim \mathrm{s}_{6}$ の位置 $\mathrm{x}_{1} \sim \mathrm{x}_{6}$ は予め 静的な試験によって求められている。よってアルミ棒下 端がセンサ $\mathrm{s}_{\mathrm{i}}$ を通過した後センサ $\mathrm{s}_{\mathrm{i}+1}$ を通過するまでの 間の平均速度 $\mathrm{V}_{\mathrm{i}}$ は

$$
v_{i}=\left(x_{i+1}-x_{i}\right) /\left(t_{i+1}-t_{1}\right)
$$

より求められ，各セン叛間での速度は一定として变位を 求める。なお㗬速引倨りにおいてはセンサの検出遅れ時 間が無梘できなかったので次式によって 図7(b)に一点鎖線で示すような伸びー時間曲線が得ら れる。

$$
V_{1}=\left(x_{i}+1-x_{i}\right) /\left(t_{i+1}-t_{1}+\Delta t_{i}\right)
$$

ここで, $\mathrm{t}_{\mathrm{i}} と \mathrm{t}_{\mathrm{i}+1}$ の遅れ時間の差 $\Delta \mathrm{t}_{\mathrm{i}}$ は $1 \mathrm{~m}$ の高さからら ルミ棒を落下させた子借実験により較正した。

な㧍、デジタルメモりに記録したデー夕はたたちにパ ーソナルコンピュータ（NEC 製 PC-9800Vm2)に取り迟

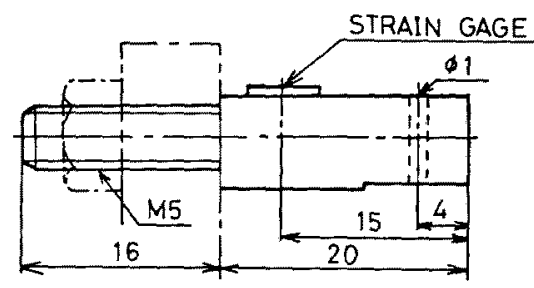

(a) CANTILEVER

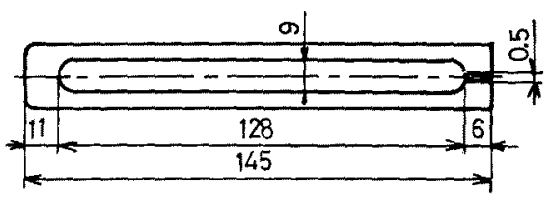

(b) ALUMINUM BAR
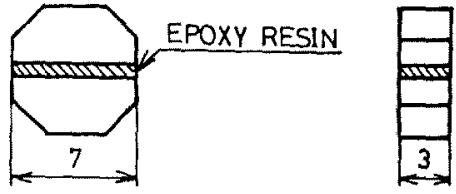

(c) ALUMINUM CHIP
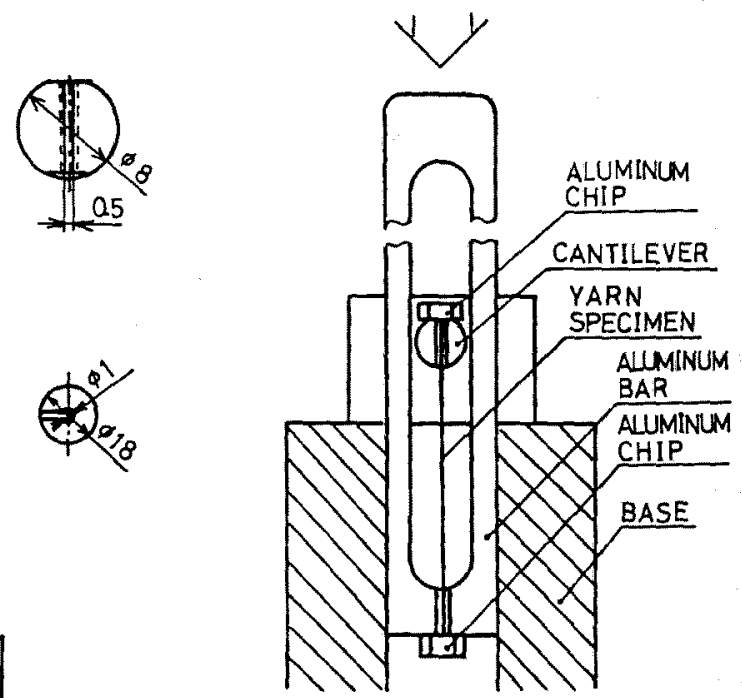

(d) YARN SPECIMEN ATTACHED TO APPARATUS

Fig. 2. Details of main parts of measurement system. 


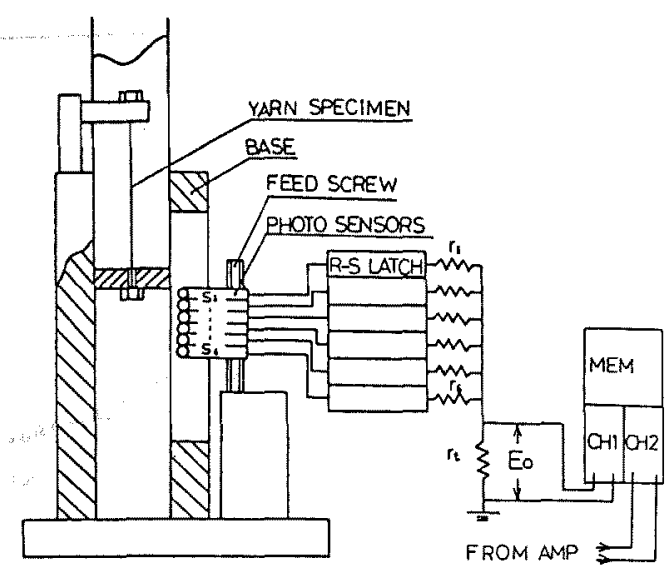

Fig. 3. Schematic diagram of displacement measurement system.

み，必要な処理を施した。

\section{2 実駼方法}

引張速度は表 $1 に$ 示す 4 種類に設定した。条件番号

Table 1 Strain Rate

\begin{tabular}{|c|c|c|c|c|}
\hline Term number & (1) & (2) & (3) & (4) \\
\hline Tensile speed $(\mathrm{m} / \mathrm{s})$ & $\begin{array}{c}1.67 \\
\times 10^{-4}\end{array}$ & $\begin{array}{c}1.67 \\
\times 10^{-3}\end{array}$ & 0.415 & 3.76 \\
\hline$\left(s^{-1}\right)$ & $\begin{array}{c}3.33 \\
\times 10^{-3}\end{array}$ & $\begin{array}{c}3.33 \\
\times 10^{-2}\end{array}$ & 8.30 & 75.2 \\
\hline
\end{tabular}

(1)，(2)の低速度での実験では定速引張試䮖機(果洋測器 製テンシロン UTM III 型)を利用して入力棒を押し下げ ることにより試料を定速で引張した。また(3)，(4)の高速 域ではガイドを介して重りを落下させ，アルミ棒に衝揧 速度を与え，系を引張した。

試料は織維の標準状態 $\left(20^{\circ} \mathrm{C}, 65 \% \mathrm{RH}\right)$ 中に 12 時間以 上放㯰し，その条件下で実験を行った。

なお，本報では応力の単位として引張前の織度で荷重

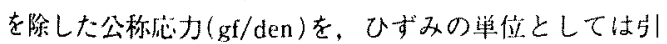
張前の陚料長で変形の長さを除した公称ひずみをそ机ぞ れ用いることにする。

\section{3 系試料}

系詶料は、ポリエステル連続マルチフィラメント釆

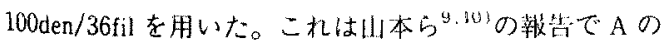
原系として用いられた系に近いもの(緎度やフィラメン 卜数は簧なるが，延伸時の熟处理温度が同じ)で，一般 的なポリエステル亲に比へてて結品化度が約 $40 \%$ ，配们性 が䄪 $2 \%$ 低いと考えられる糸である。

試料長は，一定速度の引張試騃では $50 \mathrm{~mm}$, 応力緩和
試験では $500 \mathrm{~mm}$ とした。

\section{3. ポリエステルフィラメント系の構成方程式}

\section{1 過応力模型}

ポリエステル系の応力ーひずみ特性を予想するため, 過応力模型11.12)を用いる。過応力論は北川らがポリエ チレン ${ }^{13)}$ およびポリブロピレン14の棒材の压縮やねじ りの挙動を説明するために用い，良好な結果を得てい る。

過応力模型による權成関倸の出発式は

$$
\begin{aligned}
& \mathrm{K}[*] \dot{\sigma}+\sigma=\mathrm{M}[*] \dot{\varepsilon}+\mathrm{g}[\varepsilon] \\
& \mathrm{M}[*] / \mathrm{K}[*]=\mathrm{E}
\end{aligned}
$$

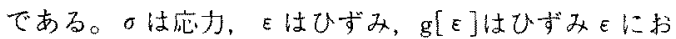
いて $\dot{~} や \dot{\varepsilon} の$ 影響がないときの応力であり，平衡応力と

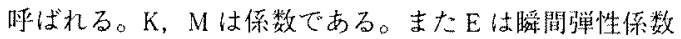
であり，本報のポリエステルマルチフィラメント糸の場 合，実䮖値より $80 \mathrm{gf} / \mathrm{den}$ を用いた。そしてドットは時 閣に関する微分，[*]は引数“*”の関数であることを示 す。(3)式でKおよび Mが応力やひずみに依存しない 一定值を取る場合には，線形粘弾性模型の一つである 3 要素模型に対応する式となる ${ }^{13 !}$ 。式( 3 )在変形速度の 形に書き換えると，

$$
\dot{\varepsilon}=\dot{\sigma} / \mathrm{E}+(\sigma-\mathrm{g}[\varepsilon]) /(\mathrm{EK}[*])
$$

となる。右辺第 2 項に含まれる $\sigma-\mathrm{g}[\varepsilon]$ は平衡応力か らのずれを表わし，過応力と呼ばれる。Kremple ${ }^{12}$ は特 にK[*]を過応力のみの関数であるとの提案をして扩 り，前述の北川らの紹果もこ机を支持している。

\section{$3.2 \mathrm{~g}$ 関数の決定}

式（5）を計算する上で $\mathrm{g}[\epsilon]$ をできるだけ精度良く求 める必桉がある。g[ $\varepsilon]$ を求めるため，ひずみ速度一定 $\left(\dot{\varepsilon}=3.3 \times 10^{-2} \mathrm{~s}^{-1}\right)$ の悯によって所定のひずみに達し

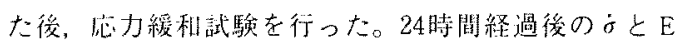
の比は $10^{-9} \mathrm{~s}^{-1}$ と極めて小さな值となるためこの心力值

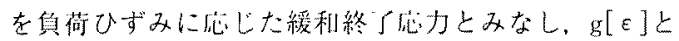
した。

园 4 டg[ $[\varepsilon]$ 示す。この曲線の形状は Kremple ${ }^{151}$ ら がSUS304ステンレス鍓について求めた応力ーひずみ曲 線の形状に近いので，これに従ってg関数を定式化し た。以下にその概略を矿す。

曲線㳘原点付近の做き $\mathrm{E}$ からゆるやかに，考慮して いる嵌大ひずみでの接線の倾き $\mathrm{E}_{\mathrm{t}}$ へと移っている。 は $\mathrm{d}^{2} \sigma / \mathrm{d} \epsilon^{2}$ の絶对值が最大值を示すときのひずみ，の は 表わすために $\mathrm{x}=\varepsilon / \varepsilon^{*}$ として次のように阔数 $\mathrm{F}(\mathrm{x})$ を分 莪する。 


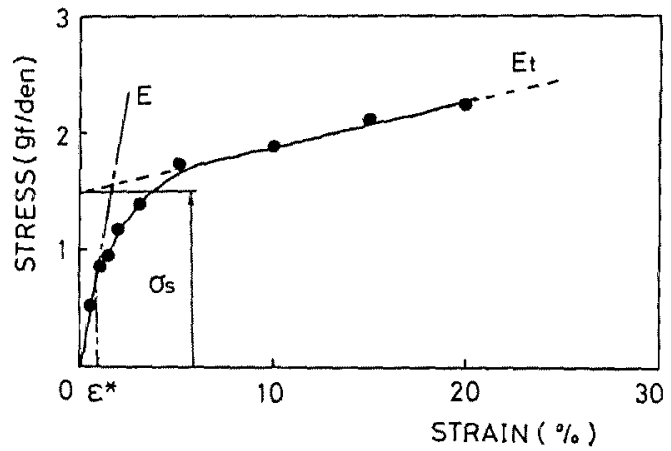

Fig. 4. Stress-strain curve of equilibrium stress. The solid curve denotes function $g[\varepsilon]$ calculated from eq. (8). The solid circles are the experimental data. $E$ is the slope at $\varepsilon \rightarrow 0$ and $\mathrm{E}_{\mathrm{t}}$ is the slope at $\varepsilon=25 \%$.

$-\frac{\mathrm{d}^{2} \sigma}{\mathrm{d} \varepsilon^{2}}=\mathrm{F}(\mathrm{x})=\mathrm{Ax}^{2 \mathrm{n}-1} \cdot \exp \left\{-\left(\mathrm{ax} \mathrm{x}^{2}+\mathrm{b} / \mathrm{x}^{2}\right)\right\}$

応力ーひずみ関係は式( 6$) 02$ 階積分から得ら机る。

$$
\sigma=\mathrm{E} \varepsilon-\int_{0}^{\varepsilon} \int_{0}^{\xi} \mathrm{F}\left(\frac{\eta}{E^{*}}\right) \mathrm{d} \eta \mathrm{d} \xi
$$

または

$$
\sigma=\left|E-\varepsilon^{*} \int_{0}^{\varepsilon / \varepsilon^{*}} \mathrm{~F}(\xi) \mathrm{d} \xi\right| \varepsilon+\varepsilon^{* 2} \int_{0}^{\varepsilon / \varepsilon^{*}} \xi \mathrm{F}(\xi) \mathrm{d} \xi(8)
$$

図4より十分大きいにに対しては

$$
\sigma=\sigma_{\mathrm{s}}+\mathrm{E}_{\mathrm{z}} \varepsilon
$$

\&o

$$
\begin{aligned}
& \int_{0}^{\infty} \mathrm{F}(\eta) \mathrm{d} \eta=\frac{E-E_{1}}{\varepsilon^{*}}=\alpha \\
& \int_{0}^{\infty} \eta \mathrm{F}(\eta) \mathrm{d} \eta=\frac{\sigma_{z}}{\varepsilon^{* 2}}=\beta
\end{aligned}
$$

式(10)および式(11)を式(6)に代入することによって

$$
\begin{aligned}
& A \cdot(b / a)^{n} \cdot K_{n}(2 a b)=\alpha \\
& A \cdot(b / a)^{n+1 / 2} \cdot K_{n+1 / 2}(2 a b)=\beta
\end{aligned}
$$

を得る。 $\mathrm{K}_{\mathrm{m}}$ は $\mathrm{m}$ 次の変形ベッセ儿関数 ${ }^{16,17) て ゙ あ る 。 ~}$

また，xの定義より，

$$
a^{2}-b^{2}+1 / 2=\pi
$$

Kremple $5^{(5)}$ は $n=0$ として定数 $\mathrm{A}, \mathrm{a}, \mathrm{b}$ を定め, 式 (8)を評価している。本報でもこれに还い，图4に○で 示した24時間後の応力緩和試騃結果より各定数を定め t:o

\section{$3.3 \mathrm{~K}$ 関数の決定}

$\mathrm{K}$ 関数は前述の心力緩和試験によって決定した。図 5 に過応力 $(\sigma-\mathrm{g}[\varepsilon])$ と緩和時間の関係を示す。緩和に上 る応力は初め，緩和試騇に先立つ定速引張のひずみ速度

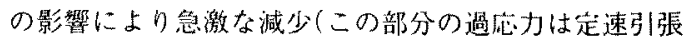
時のひずみ速度によって翼なる。)を示し，その後緩和時 間の社数に祄し，直線的に減少与る。

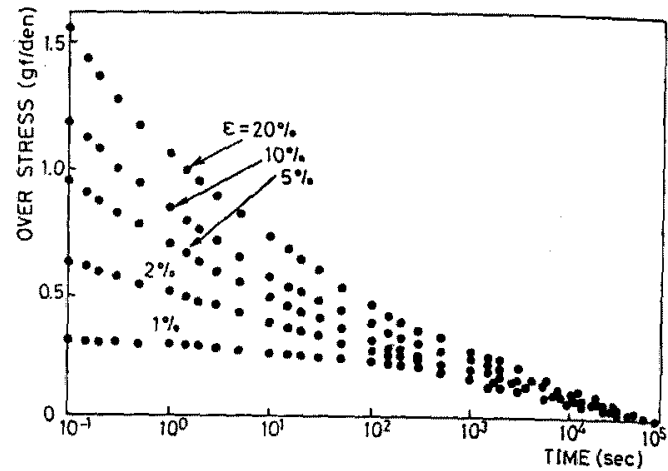

Fig. 5. Relation between over-stress and relaxation time.

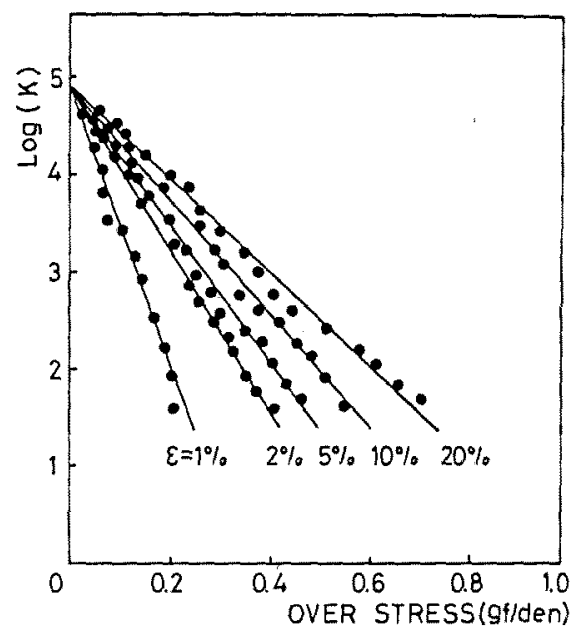

Fig. 6. $K$ plotted against over-stress at different strains.

\section{応力緩和試騃では式(3)は}

$$
\dot{\sigma}=-(\sigma-\mathrm{g}[\varepsilon]) / \mathrm{K}[*]
$$

と書き直され，各々のひずみレベルでの過応力ー時間曲 線から K「*]がかかる。これより求めた $\mathrm{K}[*]$ と過伈力 の関係を图6に示吉。 $\mathrm{K}[*]$ は $(1)$ 過拉力の減少関数て あり，加(2)ひず加の増加関数となるため，

$$
\begin{aligned}
& \mathrm{K}=\mathrm{K}_{0} \exp \left\{-\mathrm{K}_{1}[\varepsilon](\sigma-\mathrm{g}[\varepsilon])\right\} \\
& \mathrm{K}_{1}=\mathrm{P}_{0}+\mathrm{P}_{1} / \varepsilon
\end{aligned}
$$

と近似した。g関数は24時間後の緩和岕力估であるか ら，式(16)において $\mathrm{K}_{0}=86,400 \mathrm{~s}^{-1}$ とし，片剂数軲上て の緩和曲線の傾きから $K_{1}$ を定めた。。㐫力緩和試験の結 果より得られた各定数は， $\varepsilon^{*}=0.006 ， A=6.690 \mathrm{gf} /$ den, $a=0.1198, \quad b=0.7172, \quad P_{0}=5.22$ den $/ \mathrm{gf}, \quad P_{1}=$ $0.101 \mathrm{den} / \mathrm{gf}$ であった。

以上より，式( 5 )を評侕するための全ての関数形およ び定数が定まったので，ルンゲ・タッタ法により，実娩 


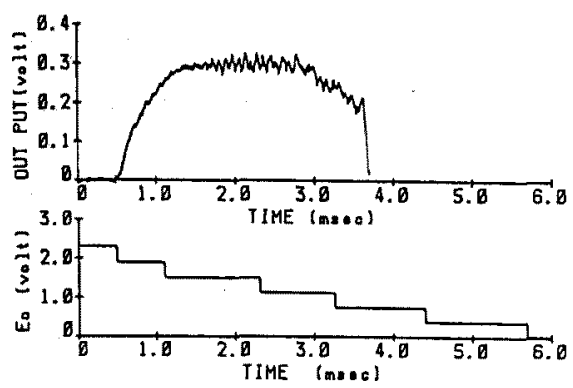

(a)

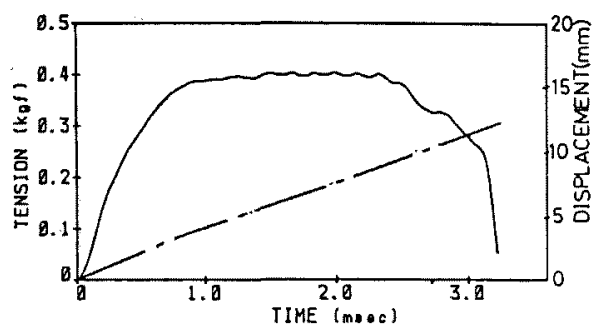

(b)

Fig. 7. Typical results as a function of time at strain rate of $80 \mathrm{~s}^{-1}$. (a) Experimental data of tensile force and $\mathrm{E}_{0}$. (b) Tension and displacement after operations by personal computer. Solid line is curve of tension, and dash-dotted line is curve of displacement

に用いた各ひずみ速度について数值計算を行った。その 結果を图 8-11に実線で示す。

\section{4. 実験結果および考察}

本研究で試作した装眲により得られた荷重一時間，お よび伸び-時間曲線の一例として条件(4)の中の1デー夕 を图 7 に示す。図 7 (a)はデジタルメモりに記録された 動ひずみ計(上段)拉よび光電センサ列(下段)からの出力 電圧である。図2(a)に示した片持はりを 88 の均一な 円形断面と仮定すれば，その横振動の 1 次の固有振動

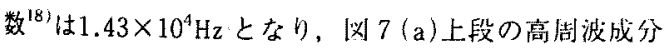
がれに相当する。この高洼波成分の振幅は，间汹に示 すように小さいので，各测定点に対して前後10点(各点 のサンプリング間揣は $5 \mu \mathrm{s}$ )の移動平均を行ってこの高 周波成分を取り除いた。得られた荷重一時間曲線を龱 7 (b)に实線で示す。一方, 光電セン州列から得られた図 $7(\mathrm{a})$ 下段の出力電圧は ( 2 )式の処理によって, 同龱 (b)の一点鎖線に示す伸びー時間曲線となる。

各引張速接において図 7 (b)ような10本の曲楾を数值 平均し、時間パラメータを消去して横軸を伸びにする と，图11の破線に示す仙力ーひずみ曲線が得られる。な お图 7 (b)加図11を得る過程に扔いて，初荷重(試料

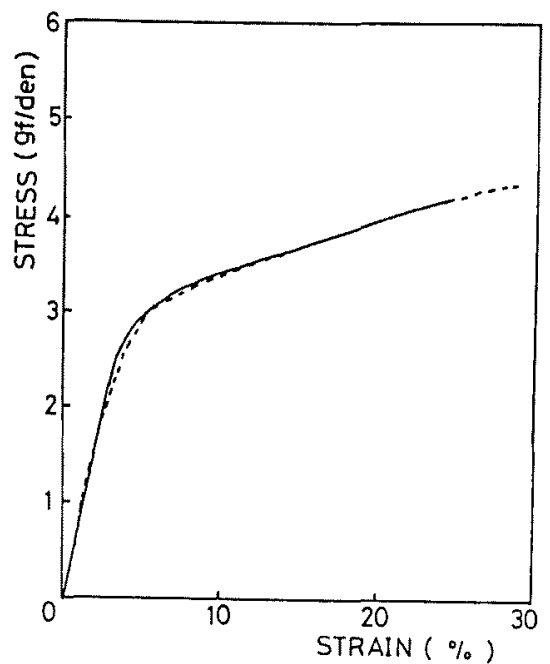

Fig. 8. Experimental (dotted) and theoretical (solid) stress-strain curves of polyester yarn at $\dot{\varepsilon}=3.33 \times 10^{-3}$ $s^{-1}$

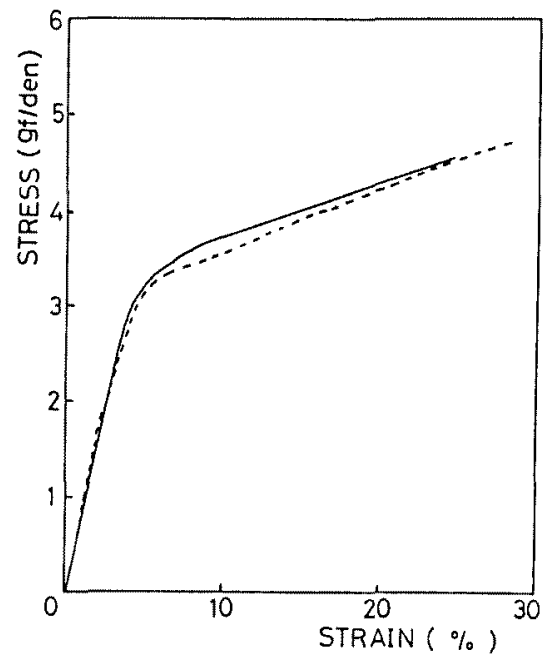

Fig. 9. Experimental (dotted) and theoretical (solid) stress-strain curves of polyester yarn at $\dot{\varepsilon}=3.33 \times 10^{-2}$ $s^{-1}$

を保持するためのアルミ棒の重量48gf)老考虑し，曲線 を原点における接線力们に48gf 分たけ延长した。

図8〜11に各ひずみ速度に扮ける数値計算結果と実騃 結果をそ机ぞれ实線および破線で示す。四8および9を

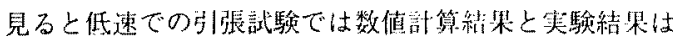
ほほ全ひずみ域で一致し，過灾力模型が有効であること が確認される。

一闵10および1てでは，数值計算絬果は降伏点付近ま では実験結果とほぼ一致して抢り，各ひずみ速度に扔け 


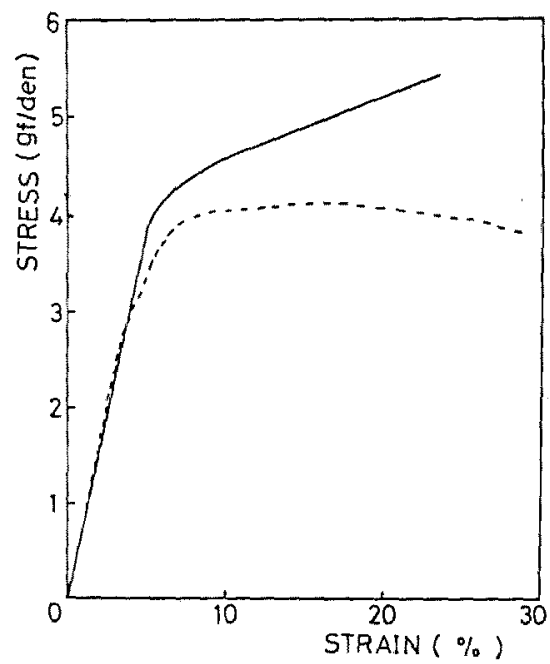

Fig. 10. Experimental (dotted) and theoretical (solid) stress-strain curves of polyester yarn at $\dot{\varepsilon}=8.3 \mathrm{~s}^{-1}$.

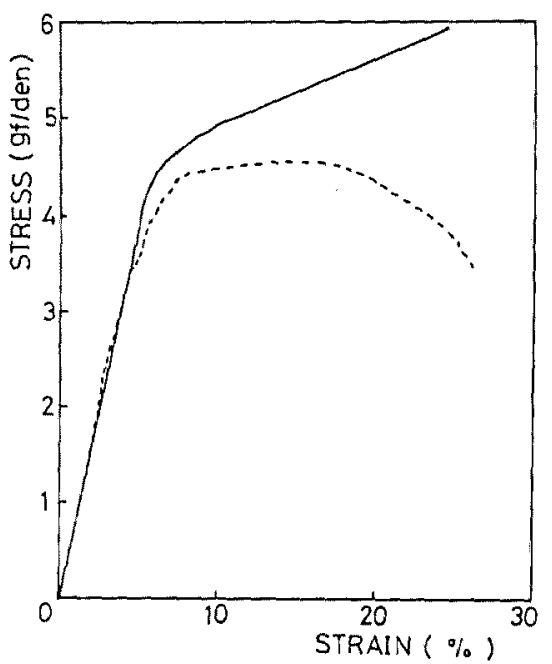

Fig. 11. Experimental (dotted) and theoretical (solid) stress-strain curves of polyester yarn at $\dot{\varepsilon}=75 \mathrm{~s}^{-1}$.

る弾性的な举動や弾性限界などを羊測するためにはこの モデルが有效であることが確認された。しかしそれ以上

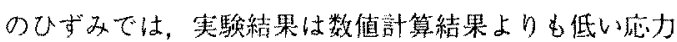
値を示し、その傾向はひずみ值が大きくなるほど，また ひな゙み速度が大きくなるほど顕著であった。このことは 式（８)では考虑していなかった温度の影箸がひずみ速度 の增加にとるなってあらわれてきたためと考えられる。 すなわちひずみ速度が大きい場合，変形により発生した エネルギが移動する時間がないため断熱变形となり、フ イラメント部で局所的に温度が上昇する。そしてこの
フィラメント内での温度上䍙により，あるひずみにおけ

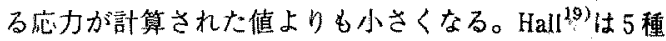
類の合成織維についてこのような䋐維内部での温度上年 を概算し，PET䄉維について $3 \mathrm{~s}^{-1}$ 以上のひずみ速度に おいて $12 \%$ のひずみレベルで $25^{\circ} \mathrm{C}$ の温度上昇があると 見積っている。

さらにこのような局所的な温度上昇の極端な例とし て、井谷ら 20,211はひずみ速度が增加するとフィラメン トの破断面が溶融状態を示すことを報告している。この ことを確諗するため各引張速度における引張試験後の系 からフィラメントを抜き取り，その破断面走查型電子 影微鏡(以下 SEM)によって観察した。その SEM 写真の 一例を図12および13に示す。図12は本実験での最低のひ ずみ速度である(1)の条件のものであるが，破断面付近は 引張により偏平になって切断されており，井谷らの棓う 延性一ぜい性の破断面を示している。一方，最大のひず み速度(4)である国13では，破断面は大きく膨らんでお り，井谷らの言う溶触状破壊を示している。

以上のことから高ひずみ速度の高ひずみ域まで適用で きる構成式に对しては温度の影響を考慮ずる必要がある と考えられ，この問題に関しては今後さらに検討が必要 である。

\section{5. 結言}

本研究では片持はりを利用したロードセルで荷重を測 定する糸の衝慗引張試験装置を試作し，ポリエステルマ ルチフィラメント禾の衝撃引張試験を行い, 試験装珇の 妥当性を確かめた。してポりエステルフィラメント采 の構成方程式として過芯力模型の適用を試みた。得られ た結果は以下の通りである。

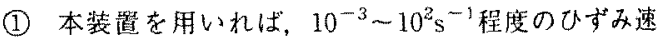
度における糸の引張試験を同一の測定系で行うことが できだ。

(2)過応力模型を用いた構成方程式により，低ひずみ速 度の引張試験結果は破断までのほほ全域にわたり，高 びずみ速度の引張試験結果は降伏点付近までを子想す ることができた。

(3) 高ひずみ速度における計算値と夷験値の差は，引張 により発生する熱が原因となっていると考えられだ。 なお，本研究は1988年縺維学会秋期研究発表会および 1989年緎維学会秋期研究発表会で発表したものである。 また本報をまとめるにあたり，有益なご助言をいただ ました福井大学工学部 小形信男先生, 金沢大学工学部 茶谷明義先生，北川正䉝先生ならびに石川䝿工業誠煥場 山本 孝氏に謝意を表わします。さらに奏騒にご協力い ただいた石川県工業試験場に感謝します。 


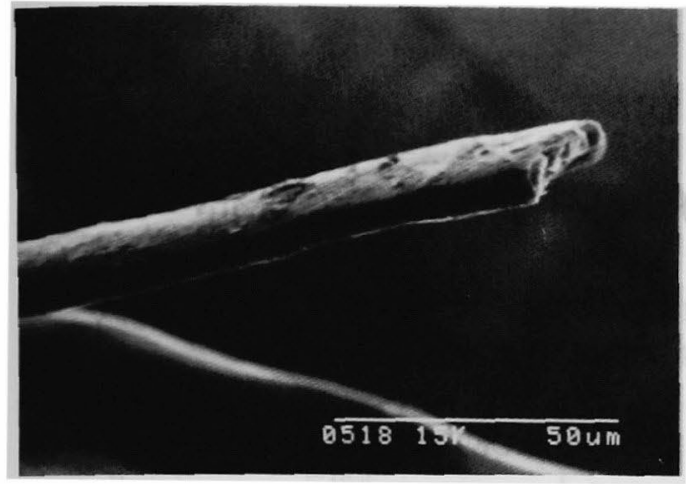

Fig. 12. SEM photomicrograph of the point of rupture tested at $\dot{\varepsilon}=3.33 \times 10^{-3} \mathrm{~s}^{-1}$.

\section{文 献}

1) W. J. Lyons, "Impact Phenomena in Textile", M. I. T. Press, Cambridge, (1963)

2 ) R. Meredith, J. Text. Inst., 45, T30 (1954)

3 ) W. K. Stone, H. F. Schifer, and G. Fox, Text. Res. J., 25. 520 (1955)

4 ) F. L. MaCrackin, H. F. Schifer, J. C. Smith, and W. K. Stone, Text. Res. J., 25, 529 (1955)

5 ) J. C. Smith, F. L. McCrackin, and H. F. Schifer, Text, Res. J., 25, 701 (1955)

6 ) J. C. Smith, F. L. McCrackin. H. F. Schifer, and W. K. Stone, K. M. Towne, Text. Res. J., 26, 821 (1956)

7 ) J. C. Smith, P. J. Shouse, J. M. Blandford, and K. M. Towne, Text. Res. J., 31, 721 (1961)

8 ) I. H. Hall, J. Polym. Sci., 54, 505 (1961)

9 ) 山本 孝, 土定育英, 松本義隆, 新宅救徳, 瀻学 誌, 43，320 (1987)

10) 山本 孝, 新宅救德, 喜成年泰, 織学誌, $\mathbf{4 5}, 42$ (1989)

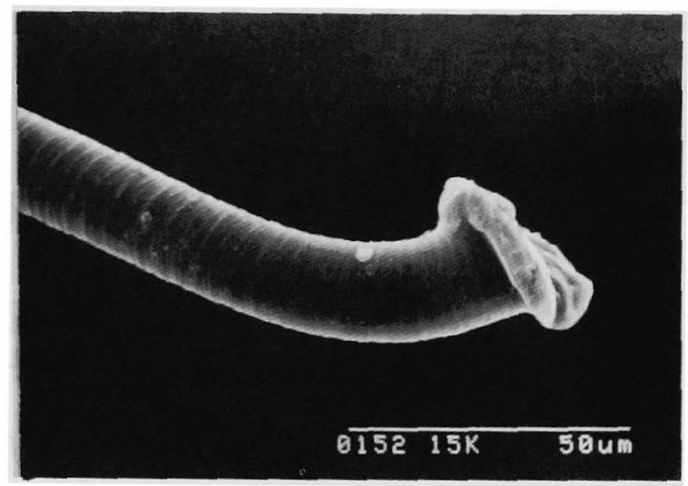

Fig. 13. SEM photomicrograph of the point of rupture tested at $\dot{\varepsilon}=75 \mathrm{~s}^{-1}$.

11) E. P. Cernocky and E. Kremple, Int. J. Non-Linear Mech., 14, 183 (1979)

12) M. C. Liu and E. Kremple, J. Mech. Phys. Solids, 27. 377 (1979)

13）北川正義, 松谷智彦, 材料, 37, 1391 (1988)

14) M. Kitagawa and T. Matsutani. J. Soc. Materials Sci.. 23. 4085 (1988)

15) M. C. Liu, E. Krempl, and D. C. Nairn, Trans. ASME Ser. H, 98, 322 (1976)

16）山内二郎, 宇野利雄, 一松 信編, 「電子計算機の ための数値計算法四」, 培風館, p. 251 (1972)

17）森口繁一, 宇田川銈久, 一松 信,「数学公式亚」, 岩波書店, p. 172 (1960)

18）小堀与一, 「実用振動計算法」, 工学図書, p. 197 (1978)

19) I. H. Hall, J. Appl. Polym. Sci., 12, 739 (1968)

20）井谷和十郎, 和田冨成, 浅田 薫, 清水保昭; 䄉学 誌, 24, 43 (1968)

21) 井谷和十郎, 和田冨成, 浅田 薫, 清水保昭; 繊学 誌, 24, 48 (1968) 